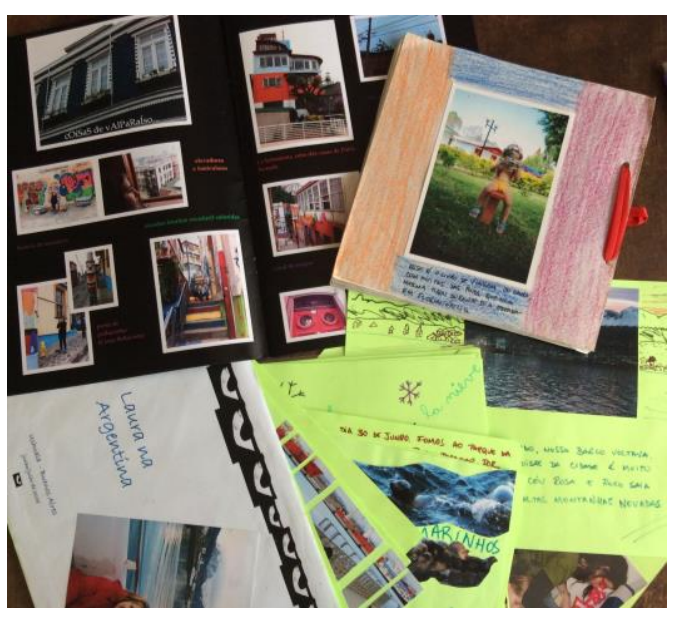

\title{
Fotografia e viagem: Reflexões sobre experiência, linguagem e memória ${ }^{1}$ Photography and travel: Reflexions on experience, language and memory
}

\author{
Daniela Palma ${ }^{2}$ \\ https://orcid.org/0000-0003-2068-0624
}

\begin{abstract}
Resumo
A experiência do deslocamento (espacial e cultural) em sua relação com a fotografia é o tema deste ensaio. O papel que a fotografia desempenha na relação entre o viajante e o lugar visitado é compreendida como mediação e como potência narrativa. Para explorar esses dois papéis, foram escolhidos dois arquétipos de viajantes fotógrafos: o correspondente de guerra e o turista. No papel de mediadora, a fotografia pode funcionar como escudo que mantém a experiência fora dos indivíduos com o sentido de proteção e distanciamento, como no caso do efeito de choque das fotografias do fotojornalista Raymond Depardon. Pode também manter a experiência fora da subjetividade no arranjo de práticas de turismo roteirizadas em escala industrial, como explorado parodicamente no ensaio Small World do fotógrafo Martin Parr. Como potência narrativa, é ressaltado o papel da fotografia de viagem nas delineações memorialísticas, em registros verbovisuais, por práticas de compartilhamento de fotografias em âmbito pessoal e familiar e na internet e, ainda, na composição de biografias imaginárias de viajantes anônimos, por meio de jogos indiciários, no trabalho L'Hôtel, da artista Sophie Calle.
\end{abstract}

Palavras-chave: memória, experiência, espaço, imagem, narrativa.

\begin{abstract}
The experience of displacement (spatial and cultural) in its relation to photography is the theme of this essay. Photography plays two roles in this relationship between traveler and the visited place: mediation and narrative potency. These two roles are explored in the paper by means of two archetypes of photographers-travelers: war correspondent and tourist. As mediation, photograph can represent the displacement of experience outside the individual when it acts as a shield of isolation and detachment as observed in the shock images of war by Raymond Depardon. Experience can be maintained alienated from subjectivity in some touristic arrangements, as explored parodically for Martin Parr in his work Small World. The narrative potency of travel photos is highlighted in some memorialistic practices of sharing personal records in domestic and virtual contexts, as also in the imaginary biographies of anonymous travelers in the performanceverbal-visual work L'Hôtel, by Sophie Calle.
\end{abstract}

Keywords: memory, experience, space, image, narrative.

\footnotetext{
${ }^{1}$ Este texto é uma versão bastante modificada de trabalho publicado nos anais do XVI Encontro da Compós, sob o título "Fotógrafos viajantes, mediação e experiência".

2 Doutora em Ciências da Comunicação USP. Docente do Departamento de Linguística Aplicada e do Programa de Pós-Graduação em Linguística Aplicada, IEL/Unicamp. E-mail: daniela.palma2@gmail.com
} 


\section{Introdução}

A história da produção fotográfica está intimamente ligada ao confronto de culturas. Meio técnico de expressão que tem, como o cinema, a modernidade em sua gênese. $\mathrm{O}$ arquétipo do fotógrafo talvez coincida com o do indivíduo-tipo da modernidade ocidental, sempre em movimento, em constante deslocar-se. Mas, se o espaço circunscrito da deriva é a grande cidade, o fotógrafo, no imaginário de suas representações, desconheceria barreiras geográficas, de línguas ou de culturas, seria o viajante, em sua acepção mais generalizante - turista, repórter, etnógrafo, imigrante.

Espécie de bússola ou escudo, a câmera fotográfica é o espaço muito valorizado de contato e confronto entre o olhar forasteiro e a paisagem que lhe é estranha. No entanto, é possível ao produtor de imagens experimentar o mundo através do visor de uma máquina? O fotógrafo viajante vivencia e faz história, experimenta o contato com o outro ou simplesmente acumula percepções? E as fotografias de viagem podem abrir portas para a compreensão das diferenças? Existe potência narrativa nesse tipo de fotografia? Essas são as indagações iniciais que animam este ensaio.

Viajar é, de forma geral, um ato que remete a uma dimensão temporal. Como afirma Sérgio Cardoso, "as viagens, na verdade, nunca transladam o viajante a um meio completamente estranho, nunca o atiram em plena e adversa exterioridade (...); mas, marcadas pela interioridade do tempo, alteram e diferenciam seu próprio mundo, tornamno estranho para si mesmo". A sensação de estranhamento das viagens não se relaciona com o outro, e sim ao próprio viajante, pois a situação "afasta-o de si mesmo, deflagra-se sempre na extensão circunscrita de sua frágil familiaridade, no interior dele próprio" (CARDOSO, 1988, p. 359). Assim, a viagem abriria uma ponte para o entendimento do próprio sujeito e disso surge toda uma mitologia em torno do ato de viajar, que é sem dúvida um dos grandes temas da literatura, das artes visuais, do jornalismo e do cinema ao longo da história ocidental.

Susan Sontag chamou atenção sobre a ligação particular entre fotografia e viagem. Ela aponta que essa relação se apoia, em parte, na sensação de poder que supostamente se teria ao olhar o mundo pelo visor: "Fotografar é apropriar-se da coisa fotografada. É envolver numa certa relação com o mundo que se assemelha ao poder" (SONTAG, 1981, p. 4). Esse "tomar posse" ajudaria o viajante a dominar um espaço que lhe causa insegurança. "Colecionar fotografias é colecionar o mundo", a autora lembra o filme Tempo de Guerra (Les Carabiniers, 1963), de Godard, em que dois camponeses entram 
para o Exército do Rei e a eles é permitida toda sorte de abusos e pilhagens contra o inimigo. Ao retornarem, a riqueza surrupiada que trazem é um saco de cartões-postais com imagens diversas de monumentos e paisagens urbanas.

Sontag ainda afirma que "a fotografia se tornou um dos principais instrumentos capazes de nos fazer conhecer determinada experiência, dando-nos a impressão de dela participar" (SONTAG, 1981, p. 10). Se se trata de "impressão", logo é uma falsa experiência, uma pseudovivência dos eventos fotografados. Adiante, completa que a imagem fotográfica não é uma simples equação do encontro entre o fotógrafo e uma determinada situação, mas o ato de fotografar transfigura-se em acontecimento, pois interfere em nosso sentido de localização, a presença da câmera fotográfica nos faz perceber o tempo como um desfile de acontecimentos, dos quais estamos aptos a selecionar os que valem a pena ser fotografados. Assim, é difícil pensar no indivíduo que fotografa como mero espectador, olhar através do visor não carrega a mesma passividade que pode ter um olhar direto, sem mediação tecnológica. Fotografar é, em alguma medida, participar. No entanto, resta a indagação sobre a qualidade dessa participação, ou seja, o acontecimento fotográfico - o contato do fotógrafo com o outro (os indivíduos, os ambientes...), contato esse, mediado pelo equipamento - perfaz-se em experiência? E, ainda, após o ato fotográfico, uma fotografia pode estimular novas experiências e narrativas? No universo dos livros, falamos em experiências de leituras, seria válido usar a mesma chave para as culturas visuais?

Para explorar a relação entre fotografia e experiências de viagem, a partir dos questionamentos levantados, escolheu-se aqui trabalhar com dois arquétipos de fotógrafos: o correspondente de guerra e o turista. No primeiro caso, foram selecionados alguns trabalhos de cobertura de guerra de autoria do fotojornalista francês Raymond Depardon como ponto de partida para refletir sobre o efeito de choque em fotografia e o seu potencial (ou não) de mobilizar sensorialidades e/ou sentimentos de alteridade. Na sequência, convido a pensar sobre uma prática como a da fotografia de turismo por meio, principalmente, de dois trabalhos contemporâneos em artes visuais. O primeiro deles, a série Small World, de Martin Parr, enquadra a fotografia como item de consumo dentro da ideia de massificação do turismo e roteirização das experiências. O segundo é L'Hôtel, de Sophie Calle, que explora o particular, com potência narrativizante, das experiências de viagem pelo que de mais previsível elas ofereceriam: o modo de ocupar um quarto de hotel. Começo, no entanto, por esboçar alguns breves apontamentos sobre sentidos de experiência. 


\section{Experiência e história}

No conhecido ensaio de Walter Benjamin, escrito em 1933 (BENJAMIN, 1993a), o autor advertia sobre o declínio da experiência na modernidade, considerações que, de certa maneira, se complementaram com o texto de 1940 sobre o conceito de história (BENJAMIN, 1993b).

Está claro que as ações da experiência estão em baixa, e isso numa geração que entre 1914 e 1918 viveu umas das mais terríveis experiências da história. Talvez isso não seja tão estranho como parece. Na época, já se podia notar que os combatentes tinham voltado silenciosos do campo de batalha. Mais pobres em experiências comunicáveis, e não mais ricos. Os livros de guerra que inundaram o mercado literário nos dez anos seguintes não continham experiências transmissíveis de boca em boca. Não, o fenômeno não é estranho. Porque nunca houve experiências mais radicalmente desmoralizadas que a experiência estratégica pela guerra de trincheiras, a experiência econômica pela inflação, a experiência do corpo pela fome, a experiência moral pelos governantes. Uma geração que ainda fora à escola num bonde puxado por cavalos viu-se abandonada, sem teto, numa paisagem diferente em tudo, exceto nas nuvens, e em cujo centro, num campo de forças de correntes e explosões destruidoras, estava o frágil e minúsculo corpo humano. (BENJAMIN, 1993a, p. 114-115)

O desenvolvimento técnico do século XIX havia se sobreposto ao homem, despejando sobre este uma mixórdia de estímulos, não cumulativos em termos históricos, que atuariam apenas no campo perceptivo. O patrimônio cultural apresenta-se então como uma extensa e categorizada coleção de feitos e objetos que respondem à reafirmação dos valores dominantes (a ideologia), desvinculados da nossa vivência, do nosso "agora", bem como dos "agoras" de nossos antepassados. Assim, a modernidade representaria não a completa negação da experiência, mas um período de declínio ou deslocamento da experiência para fora dos sujeitos. Nesse processo, em que a historicidade é enfraquecida (ou seja, os próprios sentidos de memória, os laços afetivos etc.), sobra-nos muito tempo vazio de cotidiano maçante e uma hiper-estimulação extenuante no ambiente urbano, que podemos traduzir - até certo ponto, pelo menos - em alienação.

Giorgio Agamben retoma o tema do vazio de experiências, relacionando-o com a busca pelos limites da linguagem. Segue na mesma linha de Benjamin apontado a opressão do cotidiano na cidade como causa elementar da miséria da experiência. Identifica no projeto de uma ciência moderna a expropriação da experiência, uma vez que reduziu essa última a método (empírico) ou a um campo descolado (senso comum). A distinção kantiana de um eu-penso (transcendental) e um eu-empírico esbarraria justamente no problema da linguagem. Agamben traz à crítica a noção de transcendência. Esse estado puro da razão não se daria em independência da linguagem. $\mathrm{O}$ autor afirma 
que "é na linguagem que o sujeito tem sua origem e seu lugar próprio, e que apenas na linguagem e através da linguagem é possível configurar a apercepção transcendental como um eu-penso". (AGAMBEN, 2005, p.56)

Baseando-se nos estudos de Benveniste sobre os pronomes pessoais, Agamben trabalha com a ideia de que o sujeito transcendental kantiano coincidiria com o locutor, o sujeito da linguagem como fundamento do conhecimento (eu-penso pressupõe um eufalante, a subjetividade transcendental só se dá através da linguagem, no ato da enunciação). No entanto, para Agamben, buscar a experiência em estado puro seria conceber algo que se descola da subjetividade, ou seja, o que vem antes da linguagem. Essa experiência muda, ele a chama de in-fância, ou seja, a marca do limite da linguagem.

A infância do homem não se trata de um estágio cronológico da vida humana, mas algo que deve percorrer toda essa vida e que condiciona a linguagem e seu uso. Nas palavras do autor:

Se não houvesse experiência, se não houvesse uma infância do homem, certamente a língua seria um "jogo", cuja verdade coincidiria com o seu uso correto segundo regras lógico-gramaticais. Mas, a partir do momento em que existe uma experiência, que existe uma infância do homem, cuja expropriação é o sujeito da linguagem, a linguagem coloca-se então como o lugar em que a experiência deve tornar-se verdade. (AGAMBEN, 2005, p. 62)

Assim, essa experiência inefável ao se encontrar com a linguagem produziria o conhecimento. A infância instaura na linguagem a cisão entre língua e discurso. A noção de língua permite que se conceba a ideia de uma existência muda. O homem não nasce falante, não nasce pronunciando "eu". O discurso, ou seja, a língua aprendida e em uso pelo indivíduo, dá existência ao eu-falante, o sujeito da fala. A experiência, ao cindir língua e discurso, introduz a descontinuidade, descolando a humanidade de sua natureza, dando, desta maneira, historicidade ao ser humano. A história é o instante da passagem da língua para o discurso. Nascemos não-falantes e aprendemos a falar. Manter ao longo de nossa vida essa disposição em transformar língua em discurso, em nos fazermos o "eu" da nossa fala, em dialogarmos com os outros "eus" (ou seja, em se alternar nas posições locutor e interlocutor), em produzir conhecimento, iniciar culturas, essa é a base da história para Agamben.

O empobrecimento da experiência é a expropriação da descontinuidade, é o discurso da ideologia apresentado como natural, mas que expulsa a fantasia, anulando o caráter transformador da infância e assim a própria infância. A experiência que sobraria desse processo estaria fora sujeito, não passível de ser transformada em discurso pelos 
indivíduos, como a experiência de guerra, a que Benjamin faz referência, que silenciava os soldados.

A partir dessas rápidas considerações, pretendo situar o fazer fotográfico no campo das experiências e da historicidade em dois campos que ajudam a tematizar as viagens: o jornalismo (o trabalho do correspondente de guerra) e o turismo.

\section{O correspondente de guerra}

As viagens de cobertura de guerra são emblemáticas dentro do contexto de reflexão sobre a prática jornalística, como também para pensar os sentidos gerais das experiências de relatar o sofrimento alheio. Muitas vezes, aproximar-se dos territórios da "dor dos outros" é trazer também para si a experiência do padecimento. Na análise de Ofotógrafo, graphic novel sobre a viagem do fotojornalista francês Didier Lefèvre ao Afeganistão para acompanhar uma equipe de médicos humanitários, foi explorada a forma como a jornada à região de guerra promoveu transformações no protagonista da narrativa (PALMA, 2015). Na série de videodocumentários Les 100 Photos du Siècle (1997), o fotógrafo francês Christian Simonpietri fala sobre sua experiência ao retratar a execução de bengalis acusados de colaborarem com o Paquistão, em Daca, 1971: "diante de tal atrocidade, a gente se refugia por trás da câmera fotográfica que, nessas horas difíceis, vira uma espécie de escudo. A gente desliga da vida, fica escondido e só vê com um olho, o outro fica fechado".

O depoimento de Simonpietri expõe a desesperada tentativa de se manter espectador da cena de horror que se desenrolava à sua frente, em não tomar parte. A prática do fotojornalismo se apoia na ideia do testemunho, o repórter fotográfico vê, presencia eventos, os mostra e prova que aconteceram. Ele é, por definição, um espectador privilegiado que traz a nós, espectadores vulgares, a ciência e a comprovação de um acontecimento ao qual presenciou. A atividade pede uma postura de não-interferência, no entanto, o fotojornalista dificilmente se apresenta como uma assistência fria, distante, pelo contrário, a boa fotografia jornalística pede proximidade e emoção. Assim, fotografar eventos traumáticos é por-se em risco, o que garante à profissão a aura mítica de heroísmo. Sontag comenta:

Parte do horror que provocam alguns feitos inesquecíveis do fotojornalismo contemporâneo, como as fotografias do bonzo vietnamita procurando alcançar o barril de gasolina ou do guerrilheiro bengalês no momento em que fere com uma baioneta o companheiro enfaixado, advém da consciência de que se tornou perfeitamente aceitável, em situações em que o fotógrafo possa optar entre a fotografia e a vida, decidir-se pela fotografia. Quem intervém é incapaz 
de registrar; aquele que está registrando não pode intervir. (SONTAG, 1981, $\mathrm{p}, 12)$

Simonpietri sentiu o peso de se aproximar e não intervir (e, em certa medida, a cena aconteceu devido à presença das câmeras - a sua e as dos outros repórteres), depois da cobertura dos conflitos em Daca, ele abandonou o fotojornalismo e passou a se dedicar à moda e aos espetáculos. A atitude de não-interferência converteu-se em trauma.

Entre os vários fotógrafos que cobriram o processo de independência de Bangladesh, além de Simonpietri, estava Raymond Depardon. Fotógrafo e documentarista, Depardon é um dos nomes mais importantes da reportagem visual na França. Na produção de seus filmes e suas fotos, viajou por boa parte da África, do Oriente Médio, do Sudeste Asiático, da Europa, da América do Sul e do Norte.

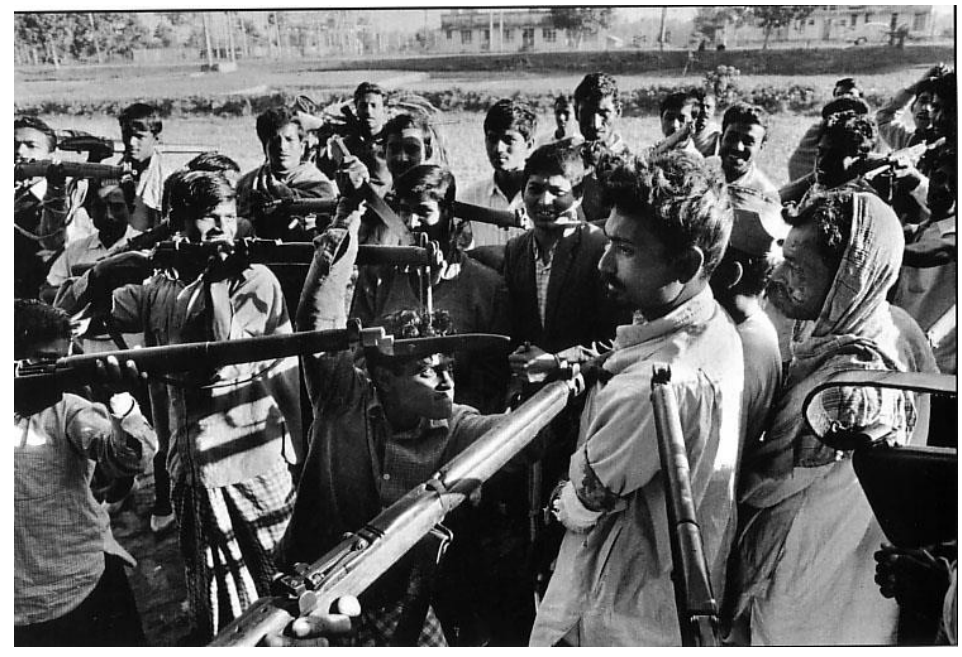

1. Raymond Depardon. Bengalis apresentam colaboracionistas capturados. Conflito indo-paquistanês. Daca, 1971.

Em uma das fotos que produziu no então Paquistão Oriental, em 1971, guerrilheiros bengalis mostram à imprensa um grupo de colaboracionistas capturados. Os guerrilheiros, aparentemente meninos muito jovens, posam para a fotografia com baionetas e facas em punho. Depardon não esconde o artifício, transparece na imagem feições dissimuladas e sorrisos leves, sem gravidade. Dessa maneira, o fotógrafo se manteria fiel aos propósitos de sua profissão - não dissimula, mas apresenta a cena "real" como uma verdadeira dissimulação. A estratégia é construir um discurso que situe o artifício no referente e não na imagem. $\mathrm{O}$ enunciador atuaria assim como o que revela, o que traz à tona o ardil. $\mathrm{O}$ pacto da "verdade" do fotojornalismo, da correspondência ao real, fica assim sedimentado. 
Em uma leitura apressada, talvez pudesse ser tirado dessa imagem um sentido mais amplo de que toda guerra moderna é também uma encenação, é tanto um acontecimento midiático quanto militar. Mas, se procurarmos ir além dessa interpretação genérica, a imagem de Depardon não nos mostra personagens da pura ficção, são guerrilheiros e prisioneiros que representam a si próprios. A documentação sobre esses conflitos narra que as pessoas que colaboraram com o exército do Paquistão e foram capturadas pelas milícias morreram executadas. Aquelas pessoas que posam de maneira aparentemente dissimulada para a câmera de Depardon (que aponta para os prisioneiros da mesma maneira que as baionetas) não são meros atores fingindo ser guerrilheiros: é bastante provável que eles tenham participado de execuções e que aqueles prisioneiros mostrados na imagem tenham sido executados longe das câmeras (ou não, já que boa parte das execuções foram públicas, como as fotografadas por Simonpietri). Assim, parece chocante ver a teatralização de uma cena que corresponde a uma situação factual brutal. A tensão entre documental e ficcional se instala. A ficcionalização do real definida como tema na imagem fotográfica promove o resguardo da aparência documentária do registro. Protege, assim, o próprio estatuto de testemunha que o fotógrafo demarca para si.

Em outra imagem, Depardon registra um prisioneiro executado amarrado aos trilhos de trem. Ao redor do corpo, os rebeldes - inclusive crianças - olham e acenam para a câmera, numa atitude que parece displicente em relação à situação de morte.

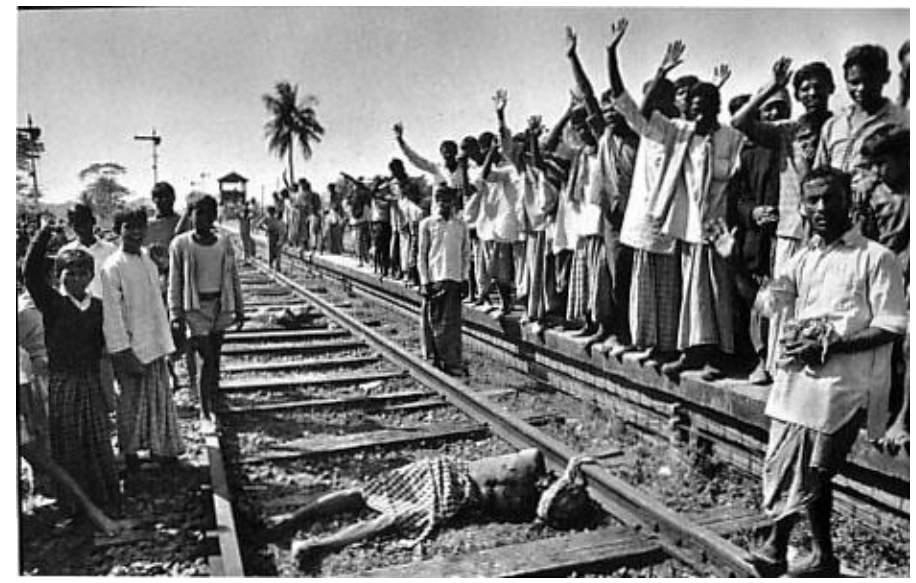

2. Raymond Depardon. Colaboracionista executado. Conflito indo-paquistanês. Daca, 1971.

Essa naturalidade que marca a forma como os bengalis são representados, posando ostensivamente para a câmera nas duas imagens, sem nenhuma ritualização para com a morte dos traidores, ecoa diretamente o imaginário sobre a banalidade da violência. Há um reforço da ideia de selvageria e de inumanidade dos retratados. As imagens demarcam 
o afastamento do sujeito que olha em relação ao outro olhado, a violência cotidiana dessas terras desoladas mais do que nos comover, nos choca (nós, espectadores, situado geopoliticamente distantes do universo retratado); é novidade, no sentido que se descola de qualquer familiaridade. Como disse Barthes, são fotos que nos apresentam não o horror, mas o "escândalo do horror". (BARTHES, 2001, p. 69)

O principal recurso de choque no fotojornalismo é a exposição da inexperienciável "dor dos outros". Como observa Sontag, "as regiões de sofrimentos memoráveis documentados por fotógrafos de prestígio nas décadas de 1950, 1960 e no início da década de 1970 situavam-se sobretudo na Ásia e na África" (SONTAG, 2003, p. 34). O choque opera, então, nesses distanciamentos - espaciais, políticos e culturais. Barthes aponta que o horror da foto-choque não está nela própria, mas "provém do fato de nós a olharmos do seio de nossa liberdade" (BARTHES, 2001, p. 67). E aí o potencial desse tipo de imagem em criar e reproduzir as mitologias - da violência generalizada, da brutalidade, do estado de natureza etc. - que Sontag identifica na representação do sofrimento de povos distantes. O mito constitui-se não no falar que se perfaz em ação (linguagem-ato), mas principalmente no "falar sobre", que demarca uma referencialidade cristalizada completamente externa à própria fala.

Existe portanto uma linguagem que não é mítica, é a linguagem do homem produtor: sempre que o homem fala para transformar o real, e não mais para conservá-lo em imagem, sempre que ele associa a sua linguagem, sempre que ele associa sua linguagem à produção de coisas, a metalinguagem é reenviada a uma linguagem-objeto, e o mito torna-se impossível. (BARTHES, 2001, p. 166)

Assim, o regime do mito é o da linguagem descolada da experiência e da capacidade de agir historicamente. Agamben explica que a experiência protege contra as surpresas, é a subtração da novidade, ou seja, neutraliza o poder de choque (AGAMBEN, 2005, p. 52). O puro estranhamento é por excelência o inexperienciável, não conseguimos agir sobre ele, o que segundo Agamben foi a base do projeto poético da modernidade e teve como expoente principal a poesia de Baudelaire. Nas imagens chocantes do fotojornalismo, o choque não representa o compartilhamento da experiência do sofrimento, diferente disso, localiza-se na brecha da experiência, no estímulo de sensações breves.

Uma das fotografias mais célebres de Depardon mostra um falangista cristão durante a invasão síria a Beirute, em 1978. A imagem carrega todos os atributos do grande fotojornalismo: muita proximidade (na verdade, parece colocar o espectador no meio da 
ação); movimento (a câmera movimenta-se, treme o cenário) e emoção. A tomada de cena poderia indicar um posicionamento na guerra, a adoção de um lado. No entanto, a foto, me parece, não transpira engajamento, não vemos pelo olho do falangista, e sim de um fotógrafo, alheio ao conflito, que acompanha a invasão. O que não significa que seja um olhar neutro, é de fora. A foto fala menos de acontecimentos políticos da região e mais de um sistema de identidades em que libaneses e sírios, cristãos ou mulçumanos, ocupam o lugar do Outro. A imagem não oferece uma causa, não propõe uma ação transformadora, apenas uma estimulação (em uma leitura anacrônica, poderíamos ler a antecipação de uma estética gameficada), uma sensação nova, só possível a quem não vive a experiência do conflito histórico.

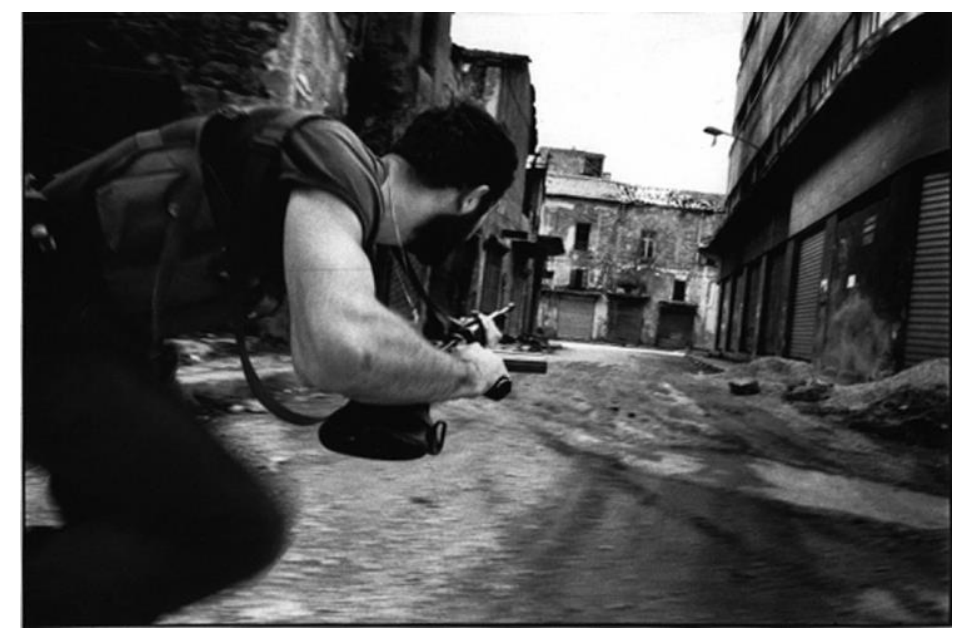

3. Raymond Depardon. Guerra Civil, Beirute, Líbano. 1978.

As imagens de guerra de Depardon registram, mas não parecem narrar. Benjamin distingue a experiência da sensação, associando-as respectivamente à narração e à informação. A narração "não tem a pretensão de transmitir um acontecimento, pura e simplesmente (como a informação faz); integra-o à vida do narrador, para passá-lo aos ouvintes como experiência" (BENJAMIN, 1991, p. 107). Ao acentuar a desorientação e demarcar a exterioridade (e a projeção de uma ideia de desumanidade nas representações das cidades de Daca e Beirute), a potência narrativa das fotos de Depardon se enfraquece, temos fragmentos de choque, cuja atuação situa-se no campo da informação, conforme a compreensão benjaminiana.

\section{Turistas}


John Urry afirma que a fotografia é elemento definidor do olhar do turista, no âmbito do turismo de massa, pois, ajuda a organizar expectativa e devaneios sobre o local a ser contemplado (URRY, 2001, p. 187). Uma vista de um cartão postal ou de uma fotografia de guia de viagem, por exemplo, oferece um enquadramento prévio do local a ser visitado, sua função é direcionar os olhares dos turistas a uma certa experiência estética. É provável que fiquem registradas na memória do viajante as cores saturadas de um céu observável somente nas páginas de uma revista de turismo.

A fotografia como prática organizadora das viagens de interesse cultural aparece já no século XIX: a produção de imagens, por fotógrafos que viajavam mundo a fora, que eram vendidas de forma avulsa ou em álbuns de vistas pitorescas. Essas fotos funcionavam tanto de souvenirs para os turistas, como também para levar "o mundo para as casas daqueles impossibilitados de fazer tais viagens" (ROSENBLUM, 1997, p. 95, tradução nossa). As imagens de viagem configuraram um mercado e uma prática colecionista que passou a envolver cartões-postais, guias, revistas e vários outros tipos de materiais impressos - até desembocar nos formatos digitais e de compartilhamentos por redes sociais de internet no século XXI.

O desenvolvimento de câmeras portáteis e de fácil operação, por volta de 1900, até os aparelhos celulares contemporâneos permitiu a disseminação da fotografia entre amadores. Dessa maneira, a imagem fotográfica se inseriu mais capilarmente no cotidiano, principalmente, da classe média urbana, como elemento de solenização de festas e eventos que revitalizam e recriam a vida do grupo familiar ou íntimo (BOURDIEU, 1965, p. 48) e, dentre esses eventos revitalizantes, as viagens de turismo cumprem papel fundamental. Mais recentemente, as redes sociais de internet, como o Instagram e Facebook, operam de maneira similar como espaço de circulação de fotografias de viagem de cunho pessoal/íntimo/familiar.

Como afirma Sontag, "a fotografia documenta sequências de consumo efetuadas longe da família dos amigos ou dos vizinhos" (SONTAG, 1981, p.9), funcionando como prova e troféu da aventura. Viajar passa a ser uma estratégia para o acúmulo de fotografias, ou seja, para a prática de colecionar lembranças. Além disso, o aparelho fotográfico, acessório básico do viajante, funciona como uma bússola para o turista. Fotografar tem função reconfortante à desorientação extenuante da viagem, não por quebrar com o ritmo da vida cotidiana, mas, ao contrário, por inserir o tempo do trabalho e a segurança da rotina no período de recesso. "Pare, tire uma fotografia e siga em frente", método que orienta e redime da culpa, exercendo "atração principalmente para os povos 
sobrecarregados por uma ética de trabalho impiedosa, como alemães, japoneses e norteamericanos" (SONTAG, 1981, p. 10).

Fotografar é um grande acontecimento para o turista. Agamben observa:

Uma visita a um museu ou a um lugar de peregrinação turística é (...) particularmente instrutiva. Posta diante das maiores maravilhas da terra (...), a esmagadora maioria da humanidade recusa-se hoje a experimentá-las: prefere que seja a máquina fotográfica a ter a experiência delas. (AGAMBEN, 2005, p. 23)

Assim, para Agamben, a fotografia no contexto do turista não representa uma nãoexperiência, mas uma experiência fora do indivíduo, logo pobre em historicismo. Paralelo curioso podemos estabelecer com Um Filme Falado (2003), do diretor português Manoel de Oliveira. A personagem central, uma professora de história, empreende uma viagem em um cruzeiro marítimo para mostrar à sua filha, locais emblemáticos da história ocidental, locais esses não visitados anteriormente pela mãe, mas, sobre os quais, ela discorre didaticamente o conhecimento livresco. A fala da mãe, apesar de cheia de afeto para com a filha, pouco difere das falas dos guias que acompanham os grupos de turistas com que cruzam. No filme, a mediação não acontece pela fotografia, mas pela palavra. A palavra no filme também se apresenta como uma experiência que está fora do sujeito falante. E quem insurge na narrativa como sujeito da experiência é justamente a criança que, com suas perguntas pueris (ou seja, também com a palavra), procura estabelecer vínculos entre os ensinamentos históricos e o "agora" experimentado.

A fotografia representa uma suposta democratização das experiências de viagem, "transformando tudo em imagem e possibilitando que qualquer pessoa as fotografe" (URRY, 2001, p. 186). Nos Estados Unidos, há roteiros de atrações “indígenas”, criadas especialmente para serem fotografadas. Em regiões do continente africano, há tempos, a caça foi substituída pelo safári fotográfico. Em frente ao Coliseu de Roma, "gladiadores" posam para retratos por alguns trocados. As experiências do turismo localizam-se no campo do consumo, são arquitetadas e roteirizadas, por meio de um aparato industrial.

$\mathrm{Na}$ fotografia, o turista encontra um canal para se apoderar de paisagens de apelo romântico saídas das páginas das revistas e guias e de vivenciar sensações de um repertório universal. Posar ao lado de uma ruína ou com um vulcão ao fundo, além de comprovar que o turista esteve lá, forja o seu vínculo com uma história da qual ele foi expropriado ou com uma natureza da qual o ritmo do trabalho o afastou. Assim, nesse tipo de fotografia o turista pode se assemelhar a um decalque. Recentemente, o artista Shahak Shapira criou e divulgou o projeto Yolocaust (que também passou a ser usada 
como hashtag em redes sociais de internet) utilizando selfies - postadas no Instagram, Facebook, Tinder e Grindr, de turistas posando no Memorial do Holocausto em Berlim montadas sobre imagens de arquivo de campos de concentração. O projeto de Shapira explora justamente essa desconexão entre as poses (que acabam por remeter a um repertório de poses de retratos de viagem) e o sentido geral de um patrimônio traumático como o memorial.

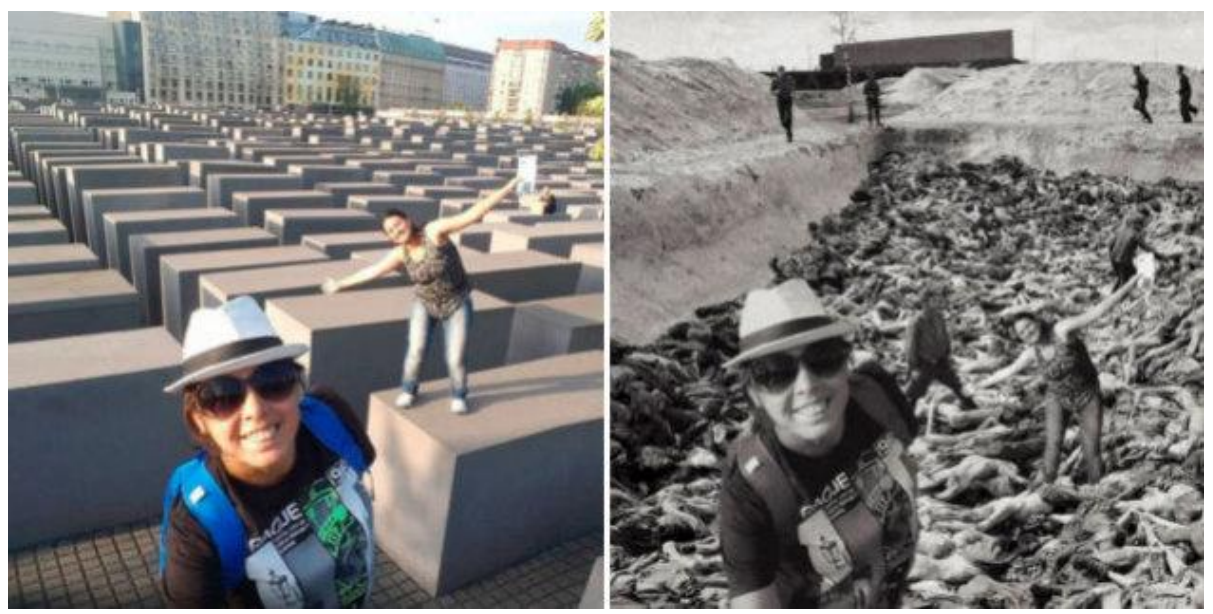

4. Shahak Shapira. Yolocaust. Berlim, Alemanha, 2016.

Por essa lógica da padronização de modelos imagéticos dentro de uma certa "coreografia" no contexto do turismo comercial, a ideia de vivenciar o contato com outra cultura pode ficar resumida à obtenção de imagens fotogênicas que correspondam aos estereótipos de exotismo, reverência, rusticidade etc. A fotografia para o turista, na dinâmica do consumo em seu traçado padrão, não seria propriamente o espaço de descobertas ou indagações, mas um expediente de produção de imagens que também fazem parte de determinados roteiros vendidos pela indústria de diversões.

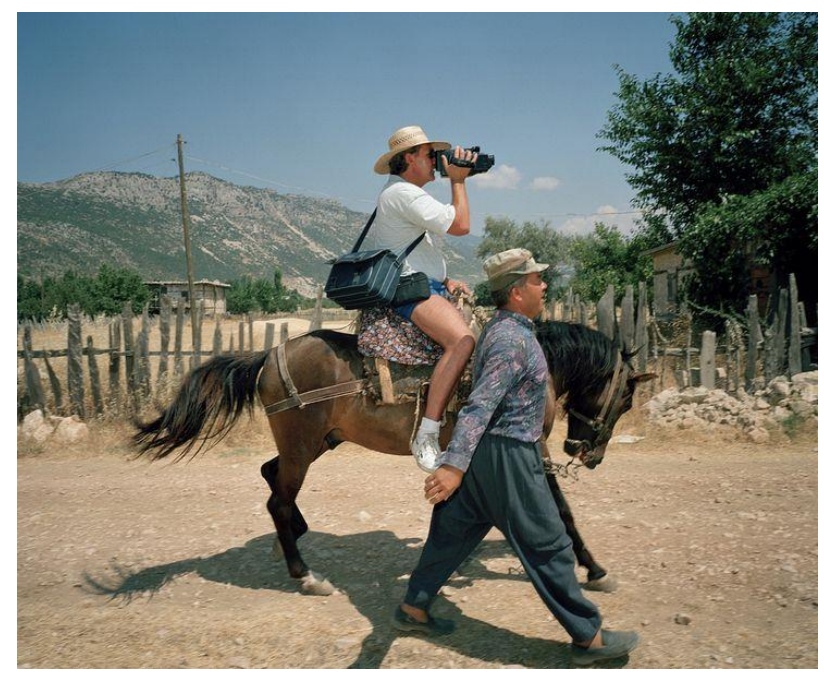


5. Martin Parr. Small World. Kalkan, Turquia. 1994.

É por essa chave de leitura dos sentidos das viagens de turismo que o fotógrafo britânico Martin Parr produziu a famosa e extensa série Small World (1995, 2005, 2007, 2015). Parr percorreu grandes pontos de peregrinação turística do mundo e produziu imagens que ampliam ou deslocam o enquadramento do eixo focal padrão dos sightseeing, expondo não apenas o artifício das vistas de turismo (as camêras dos turistas são os objetos de cena mais eloquentes em suas composições - câmeras mecânicas, digitais, filmadoras, celulares e apetrechos como objetivas, tripés, "paus de selfie" etc.), como também o não fotogênico. Nas tomadas de Parr, muitas vezes não conseguimos ver muito bem o marco turístico em questão, há constantemente bloqueios, ruídos, problemas de iluminação, sobreposições, angulações e enquadramento que prejudicam a visualização do cenário - rompendo com a sintaxe padrão de representação desses espaços de turismo. Também tudo o que é normalmente higienizado em imagens turísticas é mostrado: lixo, filas, guias, pessoas pedindo esmolas, vendedores, souvenirs ostensivos, visitantes exaustos, fundos falsos, poluição visual e atmosférica etc. Parr já havia explorado essa estratégia de fotografar o lado não fotogênico do turismo em séries anteriores como The last resort (1985) e Home and Abroad (1993).

Em Small World, alguns enquadramentos amplos deixam em evidência a estatura industrial dos espaços de turismo massificado. Uma preocupação recorrente na produção de imagens turísticas fotogênicas é ocultar o excesso de presenças - busca-se enquadrar o fotografado (ou grupo de fotografados) como se fosse ele o único naquele momento a desfrutar daquela paisagem. Parr, então, faz o contrário, monta quadros que denunciam muitas presenças, alguns deles são cenas bastante congestionadas (seja um parque aquático japonês que simula uma praia ou a sala da Monalisa, no Museu do Louvre, em Paris). Esses enquadramentos alargados com muitas pessoas e grupos de excursão, além de referir-se à dimensão empresarial que tomou conta da prática de viajar, também apontam para uma não experiência (ou uma experiência fora do sujeito), pois quebram com a ideia de sucessão de acontecimentos únicos, rompem com a própria potência narrativa dos registros de viagens pessoais (como marcadores que historicizam a vida, dando estofo biográfico), não contam histórias de vida, mas mostram fluxos de pessoas e produtos orquestrados pela atuação de aparatos de mercado. 


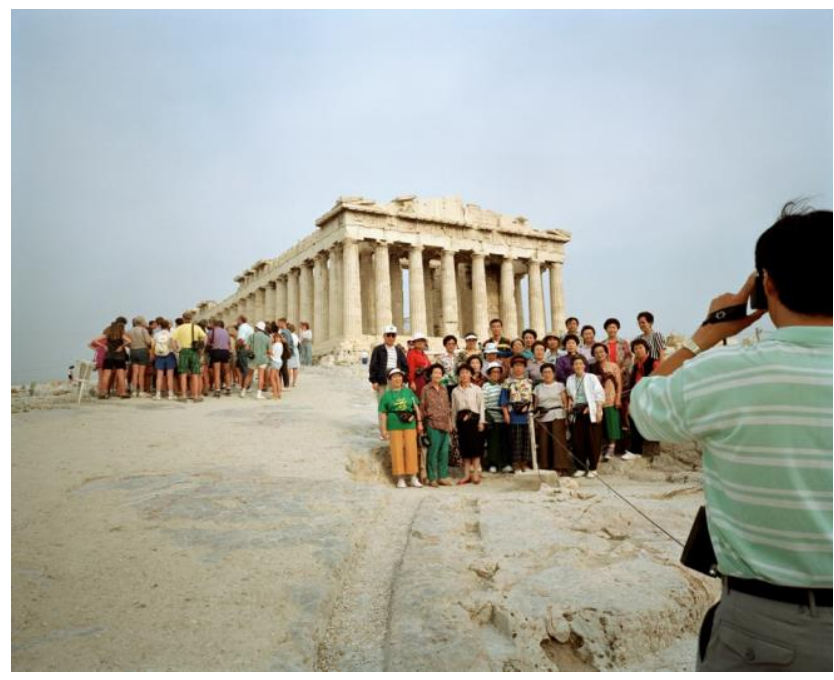

6. Martin Parr. Small World. Acrópole, Atenas, Grécia. 1991.

Para seguir esses fluxos, os corpos são adestrados, existem roteiros prontos a seguir, existem posturas e movimentos corporais pré-definidos e, frente a uma câmera, um repertório de poses. A mesma pose pode se repetir sobre uma ponte em Veneza, na Itália, e na ponte cenográfica no The Venetian Hotel em Las Vegas, nos EUA. Parr também explora esse universo de poses colocando no mesmo quadro diversas pessoas que posam simultaneamente, cada uma delas para uma câmera distinta. Como na foto junto à torre de Pisa, o deslocamento de eixo operado pelo fotógrafo cria um efeito paródico: o mesmo objeto fotografado fora do desenho perspectivo para o qual foi arranjado vira paródia de si.

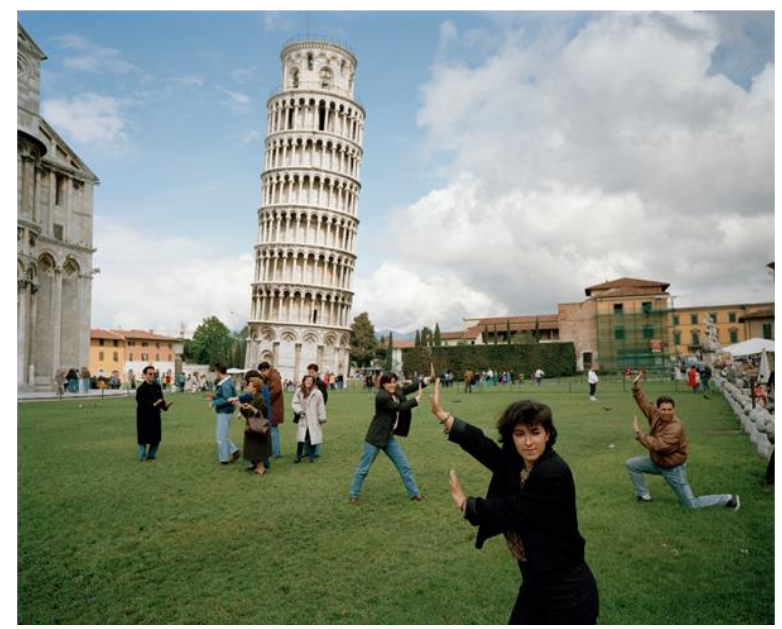

7. Martin Parr. Small World. Pisa, Itália. 1990.

\section{Fotografias que viajam}

Se as experiências das viagens de turismo convencional são ofertadas em um repertório pré-definido, como um catálogo de compras, devemos então compreender que 
não resta nenhuma brecha para o viajante atuar subjetivamente? E as fotografias trazidas de viagens de passeio, por mais que sigam moldes de produção, esgotam-se semanticamente como reprodutoras de esquemas compositivos e poses padronizadas?

Pierre Bourdieu, em seu estudo sobre a fotografia popular (ou fotografia amadora), aponta para o papel ritual que essas imagens desempenham no âmbito doméstico, na cultura da vida familiar - tomando como referência, obviamente, lares do universo popular europeu. As fotografias ordenadas em álbuns de papel (ou digitais), em séries slides para projeção (ou, mais recentemente, publicadas em perfis de Instagram e Facebook) passam a funcionar também como ordenadoras da vida fora dos álbuns (BOURDIEU, 1965): essas seleções e ordenações de imagens ritualizam encontros e interações e servem de parâmetros e estímulos para a memória individual e de grupo.

Nesses ritos (de ver junto, de compartilhar imagens), a palavra - oral ou escrita acaba por construir sentidos para as experiências de viagens fotografadas; imagens e séries de imagens ganham narratividade. O sociolinguista Louis-Jean Calvet, referindose a sociedades com forte tradição oral, atenta para organizadores simbólicos, em certas comunidades, que se se formam pela "complementariedade semiológica entre duas ordens: a ordem pictórica e a ordem linguística" (CALVET, 2011, p. 90). Analisando diversos documentos etnográficos, Calvet observa como signos visuais (grafismos, imagens, formas em cerâmicas, joias, tecidos etc.), muitas vezes, não têm significados identificáveis em si (formalmente são marcas bem esquemáticas ou padrões reproduzidos dentro de uma tradição plástica), mas precisam ser explicados ou traduzidos por um informante nativo. Como todo sentido e toda narrativa dentro de uma tradição, essas "traduções intersemióticas" são constantemente relembradas e reformuladas pelo estímulo da presença dos signos plásticos. Aponta, então, para uma relação de circularidade entre o visual e o oral: um grafismo engendra um discurso linguístico que dê sentido(s) manifesto(s) ao símbolo pictórico e este passa a funcionar como um incitador da memória, “com todos os perigos que essa função implica”. (CALVET, 2011, p. 88)

Há, assim, a capacidade de regimes sígnicos distintos se atraírem e criarem novos regimes, híbridos, a partir dessas cooperações semânticas; é nessa dinâmica que reside a potência de narrativização de imagens estáticas. Podemos, nessa linha, pensar que as fotografias que trazemos de nossas viagens, que editamos e organizamos, depois compartilhamos com um grupo maior - familiares, amigos - são imagens que, por mais que possam ter sido produzidas em uma lógica disciplinadora da indústria de turismo, 
podem ser levadas para o terreno da efabulação. Podemos pensar em costumes antigos como o de projetar slides de fotos de férias, com toda a ritualização envolvida nesse tipo de prática: a reunião de um grupo com as narrações sobre a viagem, explicações, comentários, perguntas e vários outros tipos de interações orais. E também em contextos mais contemporâneos de compartilhamento na internet - mesmo se considerarmos uma rede social como o Instagram, que privilegia as imagens, os elementos verbais (os textos das postagens e os comentários) são fundamentais na construção sentidos pessoais e afetivos para as imagens.

Uso, ainda, um terceiro exemplo do meu âmbito pessoal: costumava produzir com minha filha, por muito anos, "livrinhos de viagem" cujas as páginas eram colagens feitas com fotografias recortadas, desenhos, objetos trazidos (conchas, impressos etc.) e textos de registro memorialístico. Ou seja, na articulação dos elementos que compõem as montagens desses livros artesanais familiares, uma narrativa é emanada. Nossas lembranças pessoais daquelas viagens estão, provavelmente, muito vinculadas às imagens dos "livrinhos", muito mais do que às outras fotografias (que acabaram por formar um arquivo pessoal raramente consultado). Essas lembranças permanecem em atividade, reformulando-se. Temos o hábito de folhear esses pequenos álbuns, como também de mostrá-los a amigos: nessas situações, que têm peso de performance ou prática memorialística, reiteram-se as narrativas operadas no expediente de colagem, como também há, a cada nova consulta em contexto de interação, atualizações de significados, ressignificações, novos efeitos de sentidos.

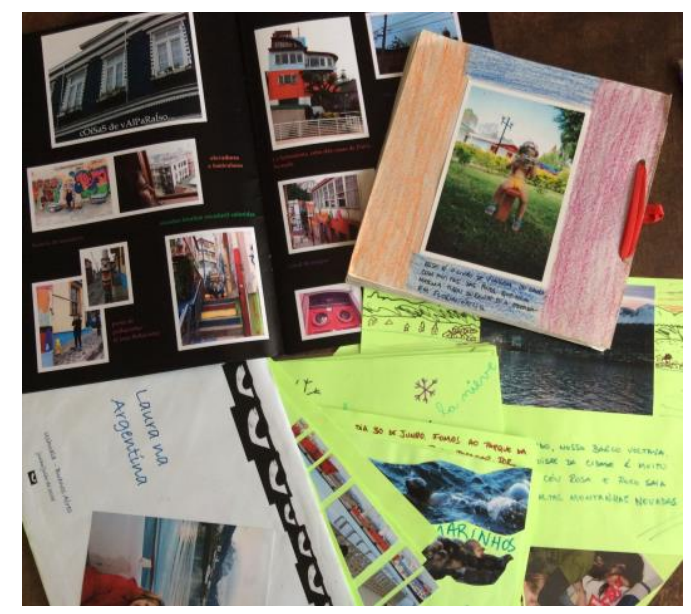

8. Arquivo Pessoal. Livrinhos de viagem, várias datas.

Diante desses e tantos outros exemplos, compreendemos que as fotografias de viagens pessoais podem ser interpretadas pela chave da padronização, ao situá-las em um plano mais amplo de sua inserção na sociedade de consumo, porém, no âmbito de sua 
circulação efetiva, ou seja, restrita, pessoal, familiar, compartilhadas e ritualizadas em interações orais ou escritas, passam a ser lidas como marcadores de experiências de vida (experiências de viagem) e junto a elas criam-se e recriam-se histórias, que são a base da constituição de nossa memória. As fotografias de viagem também viajam, mas por temporalidades.

A relação circular entre imagem e narrativas verbais e as brechas de subjetivização nas experiências de viagem são exploradas pela fotógrafa, artista e escritora francesa Sophie Calle em um de seus trabalhos mais conhecidos, L'Hôtel (1981). Aqui quem fotografa não são os turistas, mas a artista-fotógrafa que reflete sobre as experiências de deslocamento, performando uma intrusa no contexto de viagens pessoais. Dentro de propostas que mesclam performance, arte conceitual, fotografia e escrita - uma de suas marcas autorais -, Calle cria uma espécie jogo detetivesco e voyerístico. Ela empregouse, por três semanas, como camareira em um hotel em Veneza, na Itália, e nesse período, durante a limpeza dos quartos, examinou e fotografou objetos pessoais dos hóspedes e também as disposições em que as coisas eram deixadas. Ela abriu armários, inspecionou conteúdo de malas e lixeiras, leu correspondências, anotações e diários, experimentou comidas e borrifou-se com perfumes. Nessas incursões também fazia anotações em um diário de campo. Ela procurava não ter contato visual com os hóspedes, mas chegou a se postar atrás de portas para registrar diálogos e outros sons. Os resultados foram apresentados na forma de 21 dípticos relativos às ocupações de 12 quartos, durante o período em que atuou como camareira ${ }^{3}$. Na parte superior de cada díptico, um texto escrito por Calle, em forma de diário de campo, que descreve e comenta características e especula histórias sobre os personagens ocultos de seu experimento. Na parte inferior do díptico, uma sequência de nove fotos.

\footnotetext{
${ }^{3}$ Os jogos de dípticos foram produzidos em quatro edições em inglês e quatro, em francês, correspondentes a períodos diferentes do experimento de Calle. Tomamos aqui os dípticos da primeira edição em inglês que compõem o acervo da Tate Modern, Londres, Reino Unido.
} 


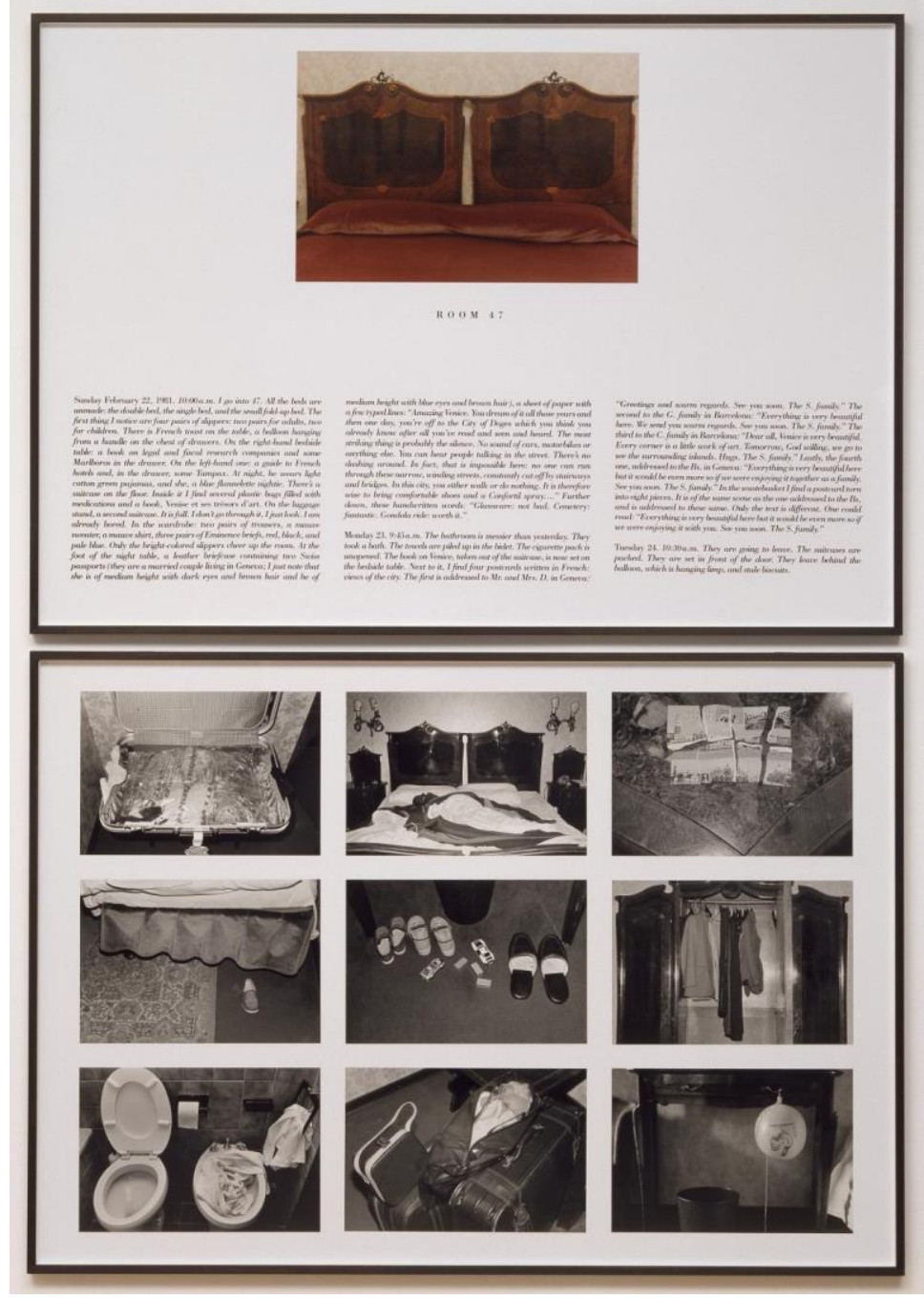

9. Sophie Calle. The Hotel, Room 47 (L'Hôtel, Chambre 47). 1981.

"Eu examinei os pertences pessoais dos hóspedes do hotel e observei, por meio de detalhes, vidas que me eram desconhecidas"4, apresenta Calle. Ao propor observar vidas por detalhes, a fotógrafa opera em uma dinâmica indiciária para ler sentidos e construir biografias (imaginárias) de viajantes. Carlo Ginzburg aponta para a permanência das formas de conhecimento constituídas a partir da observação de detalhes. Ler pistas, rastros, sintomas - a base de um modo de saber intuitivo arraigado no universo popular, apesar de bastante desacreditado por boa parte das ciências modernas. Uma personalidade (o gênio e o estilo de um pintor) se revelaria melhor "onde o esforço pessoal é menos intenso" (GINZBURG, 1989, p. 146), afirmava Morelli em seu método de autenticação de pinturas, ideia essa que teria servido como um dos pilares da própria psicanálise de Freud (ler os lapsos), segundo o historiador italiano.

\footnotetext{
4 "I examined the personal belongings of the hotel guests and observed through details lives which remained unknown to me". Disponível em: <http://www.tate.org.uk/art/artworks/calle-the-hotel-room-47p78300/text-summary>.
} 
Essas premissas parecem nortear também o método de Calle. Uma calça branca de pijama pendurada na cadeira, um par de sapatos jogado no lixo, a maneira como as roupas são guardadas em uma mala, a bagunça no banheiro, a disposição de objetos de toucador, um postal rasgado, a quantidade de malas, a quantidade de pares de sapato, o alimento abandonado, um estetoscópio, um terço, "do not disturb". Os quartos de hotel, a cada visita, por mais parecidos, nunca eram os mesmos, olhados por seus detalhes. Ao fotografar esses objetos, Calle os tira da posição secundária e lhes dá ênfase, eles viram pistas.

Essa ênfase é intensificada mais ainda pela articulação com textos que compõem os dípticos. Mantidos no formato "diário de campo", condensam observações da autoradetetive. Copio abaixo o texto do díptico reproduzido na figura 9 (Room 47):

Sunday February 22, 1981. 10:00 a.m. I go into 47. All the beds are unmade: the double bed, the single bed, and the small fold-up bed. The first thing I notice are four pairs of slippers: two pairs for adults, two for children. There is French toast on the table, a balloon hanging from a handle on the chest of drawers. On the right-hand bedside table: a book on legal and fiscal research companies and some Marlboros in the drawer. On the left-hand one: a guide to French hotels and, in the drawer, some Tampax. At night, he wears light cotton green pajamas, and she, a blue flannelette nightie. There's a suitcase on the floor. Inside it I find several plastic bags filled with medications and a book, Venise et ses tresors d'art. On the luggage stand, a second suitcase. It is full. I don't go through it, I just look. I am already bored. In the wardrobe: two pairs of trousers, a mauve sweater, a mauve shirt, three pairs of Eminence briefs, red, black and pale blue. Only the bright-colored slippers cheer up the room. At the foot of the night table, a leather briefcase containing two Swiss passports (they are a married couple living in Geneva; I just note that she is of medium height with dark eyes and brown hair and he of medium height with blue eyes and brown hair), a sheet of paper with a few typed lines: "Amazing Venice. You dream of it all those years and then one day, you're off to the City of Doges which you think you already know after all you've read and seen and heard. The most striking thing is probably the silence. No sound of cars, motorbikes or anything else. You can hear people talking in the street. There's no dashing around. In fact, that is impossible here: no one can run through these narrow, winding streets, constantly cut off by stairways and bridges. In this city, you either walk or do nothing. It is therefore wise to bring comfortable shoes and a Confotil spray..." Further down, these handwritten words: "Glassware: not bad. Cemetery: fantastic. Gondola ride: worth it."

Monday 23. 9:45 a.m. The bathroom is messier than yesterday. They took a bath. The towels are piled up in the bidet. The cigarette pack is unopened. The book on Venice, taken out of the suitcase, is now set on the bedside table. Next to it, I find four postcards written in French: views of the city. The first is addressed to Mr. and Mrs. D. in Geneva: "Greetings and warm regards. See you soon. The S. family." The second to the G. Family in Barcelona: "Everything is very beautiful here. We send you warm regards. See you soon. The S. Family." The third to the C. Family in Barcelona: "Dear all, Venice is very beautiful. Every corner is a little work of art. Tomorrow, God willing, we go to see the surrounding islands. Hugs. The S. Family." Lastly, the fourth one, addressed to the Bs. in Geneva: "Everything is beautiful here but it would be even more so if we were enjoying it together as a family. See you soon. The $\mathrm{S}$. 
Family." In the wastebasket I find a postcard torn into eight pieces. It is of the same scene as the one addressed to the Bs. and is addressed to these same. Only the text is different. One could read: "Everything is beautiful here but it would be even more so if we were enjoying it with you. See you soon. The S. Family".

O diário de campo é a amarração detetivesca que se dá pela narração subjetivada da própria "investigação" empreendida por Calle. Ginzburg identifica uma das formas mais antigas de leitura de pistas nas práticas de caça. "O que caracteriza esse saber é a capacidade de, a partir de dados aparentemente negligenciáveis, remontar a uma realidade complexa não experimentável diretamente" (GINZBURG, 1989, p. 152). Esses dados não constituídos para ser linguagem, em sua semiótica selvagem pré-semântica, são transformados em signos pelo observador que os dispõe "de modo tal a dar lugar a uma sequência narrativa, cuja formulação mais simples poderia ser 'alguém passou por lá"” (GINZBURG, 1989, p. 152). Nessa ordenação de formas semióticas brutas, o autor identifica o próprio nascimento da narrativa:

Talvez a própria ideia de narração (...) tenha nascido pela primeira vez numa sociedade de caçadores, a partir da decifração de pistas. (...) O caçador teria sido o primeiro a "narrar uma história" porque era o único capaz de ler, nas pistas mudas (se não imperceptíveis) deixadas pela presa, uma série coerente de eventos. (GINZBURG, 1989, p. 152)

O diário de Calle na amarração com as fotos estabelece uma dimensão narrativa à performance. A investigação de base indiciária tem como proposta interpretar detalhes (pistas), essas interpretações serviriam de substrato para a formulação de uma narrativa hipotética (contar o que supostamente aconteceu pela leitura de rastros). A narrativa remete a uma situação "não experenciável diretamente" por quem narra, ou seja, pelo detetive; mas Calle coloca a sua própria performance como experiência narrável (que é o expediente essencial da literatura policial). Textualmente, isso é demarcado pela narração em primeira pessoa: essa intrusa nos guia pela estória - I go into 47, isso não apenas cria um efeito de condução, mas também instaura um foco narrativo ${ }^{5}$ :

The first thing I notice are four pairs of slippers: two pairs for adults, two for children.

\footnotetext{
${ }^{5}$ Uso focalização no sentido de Genette (1995), como equivalente a ponto de vista do narrador, que aqui no caso analisado de uma obra multimodal tem maior equivalência ao sentido de campo visual, embora não se restrinja a este.
} 


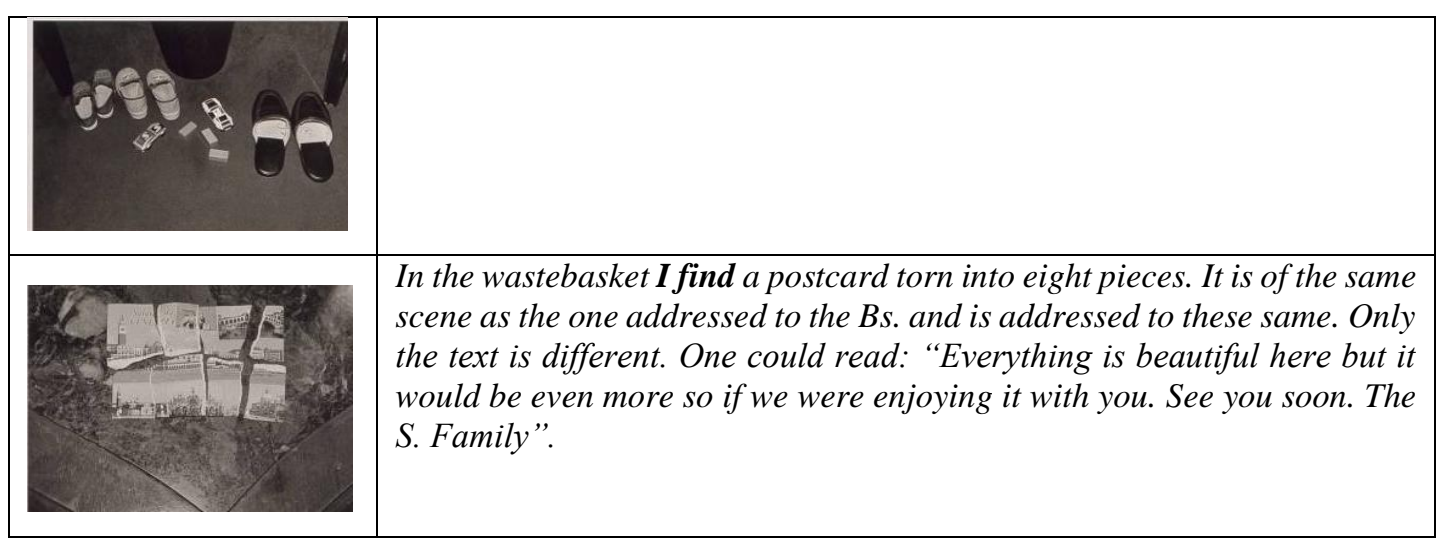

Tabela 1. Circularidade texto e imagem: foco narrativo.

A focalização narrativa instaurada pelo texto do diário tem efeito de espelhamento nas fotografias - na circularidade da relação texto e imagem, uma presença que olha é estabelecida, assumimos a perspectiva desse mesmo olhar. Além da focalização, um outro artíficio narrativo que o texto instala é o encadeamento temporal, de temporalidades que as imagens não mostram. Os fios entre os tempos são urdidos pela narração do diário que remete cada imagem a não presenças (situações de um tempo que já passou). Assim, o banheiro está "mais bagunçado do que estava ontem" e "eles tomaram banho", comentário que não descrevem a foto, mas a inserem em uma linha temporal.

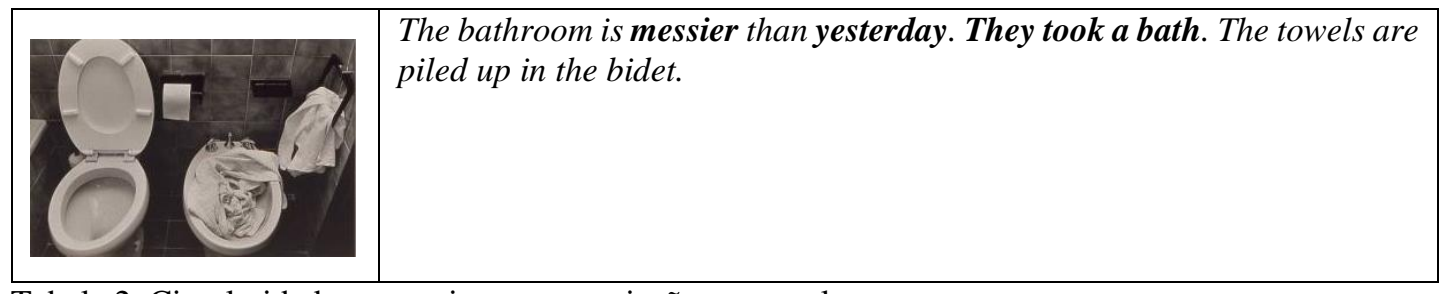

Tabela 2. Circularidade texto e imagem: projeção temporal.

Na costura texto imagem e no relevo narrativo resultante dessa operação, não temos mais um efeito de sentido de pasteurização de comportamentos, mas de reminiscências de acontecimentos. Esses acontecimentos manam da materialidade única de cada objeto, de cada pessoa, de cada enunciado, de cada experiência: a composição e disposição peculiar e familiar dos pares de pantufas ou das mensagens do postal que reata relações e afetos, o arrependimento da mensagem anterior no cartão rasgado em pedaços etc. Calle seleciona pistas que se convertem não em evidências objetivadas, mas em objetos e situações de relevo biográfico e memorialístico (o cartão postal, por exemplo, deixa de ser lido como item de consumo do turismo de massa e ganha contornos de pessoalidade em seus usos). 
Ler pistas é constituir narrativas, particularizar significados. Essa particularização em Calle começa no gesto performático da artista no papel de camareira-detetive, materializa-se na produção de fotografias-pistas e ganha desenhos de sentidos na articulação da escrita com a sequência de imagens. Para cumprir esse trajeto, a leitura dos dados não opera dentro da instituição do rigor científico, mas por meio da imaginação (poderíamos também falar em especulação como método, como propõe Josefina Ludmer $^{6}$ ), jogando as interpretações dos sentidos de vidas para o campo das poéticas, o que reafirma o estatuto da memória. Com esses expedientes, Calle restitui as experiências de vida de seus viajantes anônimos, vemos em suas representações mais idiossincrasias do que padronizações.

\section{Considerações Finais}

Uma filosofia da experiência nos permite compreender o fazer fotográfico como fenômeno que pode ter contornos e interpretações inversas, podendo contribuir, em termos mais amplos, para abrir novos caminhos epistemológicos para os estudos sobre mediações, práticas e fronteiras culturais.

Neste ensaio, busquei explorar alguns exemplos que apontam, primeiro, para questões mais estruturais que organizam os espaços de contato no âmbito dos deslocamentos e o papel mediador da fotografia. A partir de dois campos constituídos nas práticas de viagens e de produção fotográfica - o jornalismo de guerra e o turismo -, essas marcas estruturantes apareceram em torno de dois tipos de relação: estranhamento e familiaridade.

As fotografias de guerras comentadas operam por meio do estranhamento acentuado para construir o efeito de choque. Essas fotos demarcam uma separação entre o olhante (o fotógrafo e o espectador) e o olhado, o que acaba por enfraquecer as possibilidades de amarração de fios entre esses dois lados: a fotografia e a câmera fotográfica funcionam (ou acredita-se que funcionem) como um escudo de proteção que mantém o sofrimento e a violência fora da experiência de quem olha (para imagem ou pelo visor). Sobra, assim, pouco espaço para ação (abertura para novas formas de conscientização e construção de empatias, por exemplo) e/ou para a efabulação sobre lugares distantes e pessoas (outras narrativas que rompam com ou desestabilizem as mitologias coloniais).

\footnotetext{
${ }^{6}$ Ludmer propõe o pensamento especulativo que consiste em interpretar a realidade por métodos da ficção, resultando em um conhecimento amalgamado: realidadficción. (LUDMER, 2010)
} 
No campo do turismo, lido pela lente dos arranjos de mercado, a ênfase está na familiaridade excessiva, a prática fotográfica acaba por responder a roteirizações e esquemas compositivos que reduzem as chances de o acaso operar. $\mathrm{O}$ grão da novidade (e o oferecimento de riscos), também constitutivo das experiências com potencial transformador, tende a ser varrido nesses processos higienizadores das viagens. É claro que esses processos (como quaisquer outros) são cheios de contradições e o trabalho de Martin Parr justamente as explora por meio da paródia, deformando as expectativas estéticas (os sentimentos de familiaridade) até o ponto de se tornarem ou se revelarem bastante estranhas.

Por fim, aponto outras conduções epistemológicas para pensar as fotografias de viagem não como formas estáticas e de sentidos estabilizados, mas como objetos que viajam também. O deslocamento aqui não é espacial, mas temporal, por meio da inserção das imagens de viagem em regimes da narrativa. Seja por meio das ritualizações no compartilhamento das fotografias pessoais de viagem ou ainda pelo jogo indiciário de Sophie Calle para compor biografias de viajantes anônimos, imagem e palavra se amalgamam compondo registros de memória que são híbridos não apenas em sua consistência semiótica, mas também na fusão entre relato e ficção, documento e fabulação.

\section{Referências}

AGAMBEN, Giorgio. Infância e história: destruição da experiência e origem da história. Tradução de Henrique Burigo. Belo Horizonte: UFMG, 2005.

BARTHES, Roland. Mitologias. Tradução de Rita Boungermino e Pedro de Souza. Rio de Janeiro: Bertrand, 2001.

BENJAMIN, Walter. Charles Baudelaire, um lírico no auge do capitalismo. São Paulo: Brasiliense, 1991.

BENJAMIN, Walter. Experiência e pobreza. In:

Obras escolhidas, v. I: Magia

e técnica, arte e política. Tradução de Sergio Paulo Rouanet. São Paulo: Brasiliense, 1993a. pp. 114-119.

BENJAMIN, Walter. Sobre o conceito da história. In: Obras escolhidas, v. I: Magia e técnica, arte e política. Tradução de Sergio Paulo Rouanet. São Paulo: Brasiliense, 1993b. pp. 222-234.

BOURDIEU, Pierre (org.) Un art moyen: essai sur les usages sociaux de la photographie. Paris: Minuit, 1965.

CALVET, Louis-Jean. Tradição oral \& tradição escrita. Tradução de Waldemar Ferreira Netto e Maressa de Freitas Vieira. São Paulo: Parábola, 2011. p.90. 
CARDOSO, Sérgio. O olhar viajante (do etnólogo). In: NOVAES, Adauto (org.). O olhar. São Paulo: Companhia das Letras, 1988.

DEPARDON, Raymond. 100 Photos pour defendre la liberte de la presse. Paris: Reporters san frontières, 1997.

GENETTE, Gérard. Discurso da narrativa. Lisboa: Vega, 1995.

GINZBURG, Carlo. Sinais: raízes de um paradigma indiciário. In: . Mitos, emblemas, sinais. Tradução de Federico Carotti. São Paulo: Companhia das Letras, 1989. pp. 143-180.

LES 100 Photos du Siècle. Direção:. Paris: CAPA Productions/ARTE, 1997.

LUDMER, Josefina. Aquí América latina: una especulación. Buenos Aires: Eterna Cadencia, 2010.

PALMA, Daniela. O arquivo de Didier: autobiografia, humanitarismo e imagem em Le Photographe. Aletria: Revista de Estudos de Literatura, [S.1.], v. 25, n. 3, p. 181-204, abr. 2016.

ROSENBLUM, Naomi. A world history of photography. New York: Abbeville, 1997.

SONTAG, Susan. Ensaios sobre a fotografia. Rio de Janeiro: Arbor, 1981.

SONTAG, Susan. Diante da dor dos outros. Tradução de Rubens Figueiredo. São Paulo: Companhia das Letras, 2003.

URRY, John. O olhar do turista: lazer e viagens nas sociedades contemporâneas. Tradução de Carlos Eugênio Marcondes de Moura. São Paulo: Studio Nobel: Sesc, 2001.

Data de Recebimento: 31/07/2018

Data de Aprovação: 10/09/2018 


\section{Para citar essa obra:}

PALMA, Daniela. Fotografia e viagem: Reflexões sobre experiência, linguagem e memória. In: RUA [online]. Volume 24, número 2 - p. 325-349 - e-ISSN 2179-9911 - novembro/2018. Consultada no Portal Labeurb - Revista do Laboratório de Estudos Urbanos do Núcleo de Desenvolvimento da Criatividade.

http://www.labeurb.unicamp.br/rua/

Capa: Arquivo da autora. Livrinhos de viagem, várias datas

Laboratório de Estudos Urbanos - LABEURB

Núcleo de Desenvolvimento da Criatividade - NUDECRI

Universidade Estadual de Campinas - UNICAMP

http://www.labeurb.unicamp.br/

Endereço:

LABEURB - LABORATÓRIO DE ESTUDOS URBANOS

UNICAMP/COCEN / NUDECRI

CAIXA POSTAL 6166

Campinas/SP - Brasil

CEP 13083-892

Fone/ Fax: (19) 3521-7900

Contato: http://www.labeurb.unicamp.br/contato 